EDITORIAL NOTE

$W_{\text {itt }}$

th this issue, I conclude an eight-year editorship of the Journal of Interamerican Studies and World Affairs, as I plan to retire from academic life at the University of Miami on June 1, 1972.

I shall miss the Journal: the daily excitement of the mailbox surprises-sometimes a treasure chest, sometimes a Pandora's box-and the many, many interesting, rewarding, challenging, frustrating, exciting professional and personal contacts with my colleague Latin Americanists.

The problems-unexpected, critical, time-consuming, exacerbating, and frustrating-I can do without. They are, in fact, already forgotten in the satisfying realization that the Journal has now passed through its hectic, strenuous period of adolescent growth to a quieter, but hopefully even more impressive, maturity under the continuing sponsorship of the Center for Advanced International Studies, University of Miami, and with a new editorial staff.

Speaking for myself, the associated editor, Julian I. Weinkle, and the book review editor, Harry W. Hutchinson, together we say "Thank you so much" to all those who have made this possible.

It's been fun! My congratulations and best wishes to the incoming editors: John P. Harrison and Jan Peter Wogart.

-Ione S. Wright

Editor 


\section{Latin American Urban Policies and the Social Sciences}

\section{Edited by JOHN MILLER and RALPH A. GAKENHEIMER}

Accelerated urbanization and rapid population growth have drawn particular attention to Latin American in recent years. Current statistics on the growth rate of the nations of South America indicate the highest continental growth rate in the world, and there is no evidence that it may decelerate significantly.

Editors Miller and Gakenheimer have addressed various policy issues related to urban development in Latin America at international, national, and local levels from the points of view of different social sciences. The problems and potentials generated by rapid urbanization and the use of the social sciences for understanding and guiding urbanization and the process of national growth are treated extensively.

This volume is based on the Jahuel, Chile, Conference sponsored by the Ford Foundation-at which eminent scholars from both North and South America met to discuss Latin American Urban Policies.

Table of Contents

I. The New Urban Era in Latin America: A Challenge-The Urban Phase: Raison d'étre for Policy, John Miller

II. Integrating Urban-Regional Policies Among Nations-The Rapprochement of Nations with Contiguous Regions, John Miller / Economic Integration and the Spatial Development of South America, Paul Ove Pederson and Waiter Stohr

III. Urban Growth Policies for the Nation-Channeling National Urban Growth in Latin America, John Miller / The Role of Cities in National Development, John Friedmann / Planning, History, Politics: Reflections on John Friedmann's 'The Role of Cities in National Development,' Richard M. Morse / Rejoinder to Richard M. Morse, John Friedmann

IV. Political Development Vis-a-vis Urban Growth-The Distribution of Political and Governmental Power in the Context of Urbanization, John Miller / Urbanization Policy and Political Development in Latin America, Robert $T$. Daland

V. Metropolitan Policy for the Squatter Settlements-Three Proposals Regarding Accelerated Urbanization Problems in Metropolitan Areas: The Lima Case, Carlos Delgado

VI. A Future Role for the Social Sciences: Policy and Action-The Contribution of the Social Sciences to Urban Policy Formulation in Latin America, John Miller Appendix: Jahuel Seminar Summary, Kaiman H. Silvert

ISBN 0.8039-0056-2

L.C. 70-103481
1971

SAGE PUBLICATIONS, INC.

275 S. Beverly Dr. / Beverly Hills, CA. 90212
384 pages

$\$ 12.50$

Market: World 